\title{
Vulvar Keratinizing Squamous Cell
}

\section{Carcinoma}

National Cancer Institute

\section{Source}

National Cancer Institute. Vulvar Keratinizing Squamous Cell Carcinoma. NCI Thesaurus.

Code C40284.

A squamous cell carcinoma that arises from the vulva and is characterized by the presence of keratin pearls. 